\title{
X-Ray- and Neutron-Scattering Studies of $\alpha$-Crystallin and Evidence That the Target Protein Sits in the Fenestrations of the $\alpha$-Crystallin Shell
}

\author{
Justyn W. Regini, ${ }^{1}$ J. Günter Grossmann, ${ }^{2}$ Peter Timmins, ${ }^{3}$ Jobn J. Harding, ${ }^{4}$ \\ Andrew J. Quantock, ${ }^{1}$ Stuart A. Hodson, ${ }^{4}$ and Gerald F. Elliott ${ }^{1,4}$
}

Purpose. $\alpha$-Crystallin, a ubiquitous molecular chaperone, is found in high concentrations in the lens. Its structure and precise mechanism of action, however, are unknown. The purpose of these experiments was to further the understanding of the chaperone function of $\alpha$-crystallin.

Methods. X-ray- and neutron-solution-scattering studies were used to measure the radius of gyration of bovine lens $\alpha$-crystallin when complexed with its target protein $\beta$-crystallin in both normal and heavy-water-based solutions. Spectrophotometry was used as a chaperone assay.

REsults. The radius of gyration of $\alpha$-crystallin on its own and when mixed with $\beta$-crystallin was $69 \pm 1 \AA$ at $35^{\circ} \mathrm{C}$ and increased with the temperature. In contrast to $\mathrm{H}_{2} \mathrm{O}$-buffered solutions, the radius of gyration did not increase significantly in $\mathrm{D}_{2} \mathrm{O}$-buffered solutions up to $55^{\circ} \mathrm{C}$, and at $70^{\circ} \mathrm{C}$ was, on average, some 15 to $20 \AA$ smaller.

Concuusions. Bovine lens $\alpha$-crystallin in solution can be modeled as a fenestrated spherical shell of diameter $169 \AA$. At physiological temperatures, a weak interaction between $\alpha$ - and $\beta$-crystallin occurs, and $\beta$-crystallin is located in the fenestrations. Deuterium substitution indicates that the superaggregation process is controlled by hydrogen bonding. However, the chaperone process and superaggregation appear not to be linked. (Invest Ophthalmol Vis Sci. 2007;48:2695-2700) DOI: 10.1167/iovs.06-0559

$\mathrm{T}$ he primary protein component of the mammalian lens is $\alpha$-crystallin, which can approach $50 \%$ of the total dry weight of the lens. ${ }^{1}$ Its main role is as a molecular chaperone, and it protects its target proteins, $\beta$ - and $\gamma$-crystallin, from unfolding in response to environmental stresses. $\alpha$-Crystallin has two isoforms, $\alpha$-A and $\alpha$-B, each of which has an approximate mass of $20 \mathrm{kDa}$, and is expressed independently in most of the tissues of the body, with $\alpha$-B-crystallin by far the more prevalent. ${ }^{2,3}$ It seems that it is only in the lens that the two isoforms are coexpressed, and in this tissue the two coaggregate into a heterogeneous population with an average diameter

From the ${ }^{1}$ School of Optometry and Vision Sciences, Cardiff University, Cardiff, Wales, United Kingdom; the ${ }^{2}$ Synchrotron Radiation Department, CCLRC (Central Laboratory of the Research Councils) Daresbury Laboratory, Daresbury, Warrington, United Kingdom; the ${ }^{3}$ Institut Laue Langevin, Grenoble, France; and the ${ }^{4}$ Nuffield Laboratory for Ophthalmology, University of Oxford, Oxford, United Kingdom.

Supported by CCLRC and ILL Beamtime Awards.

Submitted for publication May 22, 2006; revised November 20, 2006, and January 15, 2007; accepted April 17, 2007.

Disclosure: J.W. Regini, None; J.G. Grossmann, None; P. Timmins, None; J.J. Harding, None; A.J. Quantock, None; S.A. Hodson, None; G.F. Elliott, None

The publication costs of this article were defrayed in part by page charge payment. This article must therefore be marked "advertisement" in accordance with 18 U.S.C. $\$ 1734$ solely to indicate this fact.

Corresponding author: Justyn W. Regini, School of Optometry and Vision Sciences, Cardiff University, Redwood Building, King Edward VII Ave, Cardiff, CF10 3NB, UK; reginijw@cf.ac.uk. of $\sim 15 \mathrm{~nm}$ and an overall mass of $\sim 700 \mathrm{kDa} .{ }^{4}$ This heterogeneity arises from the unusual solution properties of the $\alpha$-crystallin subunit, so that the aggregation process is driven both by ionic and hydrophobic interactions. The resultant number of subunits in each assemblage can vary considerably. $\alpha$-Crystallin also contributes to the maintenance of short-range order in the lens cytoplasm, helping to achieve the refraction of light and lens transparency in the visible spectrum. ${ }^{5}$

$\alpha$-Crystallin has a key role as a molecular chaperone, protecting target proteins against reduction-induced precipitation, ${ }^{6}$ heat-induced aggregation, ${ }^{7}$ and enzyme inactivation. ${ }^{8}$ It is involved in several pathologic situations, especially ischemic heart, ${ }^{9}$ neurologic disorders, ${ }^{10}$ and protein misfolding diseases. The structure of $\alpha$-crystallin, however, its relationship with its target protein, and the mechanism of action all remain unknown.

Previously, we studied the low-angle x-ray diffraction patterns from gels of $\alpha$-crystallin and from intact lens as a function of temperature. ${ }^{11}$ In solutions, in gels and in the intact lens the $\alpha$-crystallin aggregate underwent extensive structural changes and became much larger in response to increasing temperature, with a major transition at $\sim 50^{\circ} \mathrm{C}$. A moderate increase in the spacing and intensity of the dominant $\mathrm{x}$-ray reflection was observed in the temperature range of $20^{\circ} \mathrm{C}$ to $45^{\circ} \mathrm{C}$, followed by an accelerated increase from $45^{\circ} \mathrm{C}$ to $70^{\circ} \mathrm{C}$. We used the term superaggregation to describe the process of the enlargement of the $\alpha$-crystallin aggregates with increasing temperature. These results confirmed earlier electron microscopic, circular di, and nondenaturing gel observations of a temperature transition at $\sim 50^{\circ} \mathrm{C}$ at low concentrations of $\alpha$-crystallin in vitro. ${ }^{12}$ This transition was now seen to occur also at physiological concentrations and in situ. Although the previous x-ray diffraction results were valid for both low and high concentrations of $\alpha$-crystallin, investigating structural phenomena of this protein at almost physiological concentrations (as performed on $\alpha$-crystallin gels) is clearly important and may resolve outstanding problems concerning the operation of the system. Our previous study made it clear that $\alpha$-crystallin function in the lens is closely associated with a highly dynamic particle structure. In the present study, we used x-ray- and neutronsolution-scattering techniques to study the radius of gyration (Rg) of $\alpha$-crystallin in solutions of either water or deuterium oxide through the temperature range $20^{\circ} \mathrm{C}$ to $70^{\circ} \mathrm{C}$ and to obtain data for its modeling as a fenestrated chaperone.

\section{Methods}

All proteins used in the study were produced at the Nuffield Laboratory of Ophthalmology, Oxford University, as described by Derham and Harding, ${ }^{13}$ and are wild-type proteins with all isoforms present. Lowangle x-ray and neutron-scattering experiments were conducted at Station 2.1 at the Daresbury SRS (Synchrotron Radiation Source) and beam-line D11 at the ILL (Institut Laue-Langevin) research reactor (Grenoble, France), respectively. We used a $2-\mathrm{mg} \mathrm{mL}^{-1}$ protein concentration in solutions containing $100 \mathrm{mM} \mathrm{NaCl}$ and $0.02 \%$ (wt/vol) $\mathrm{NaN}_{3}$ buffered with $50 \mathrm{mM}$ imidazole at $\mathrm{pH}$ 7.5. These solutions were 


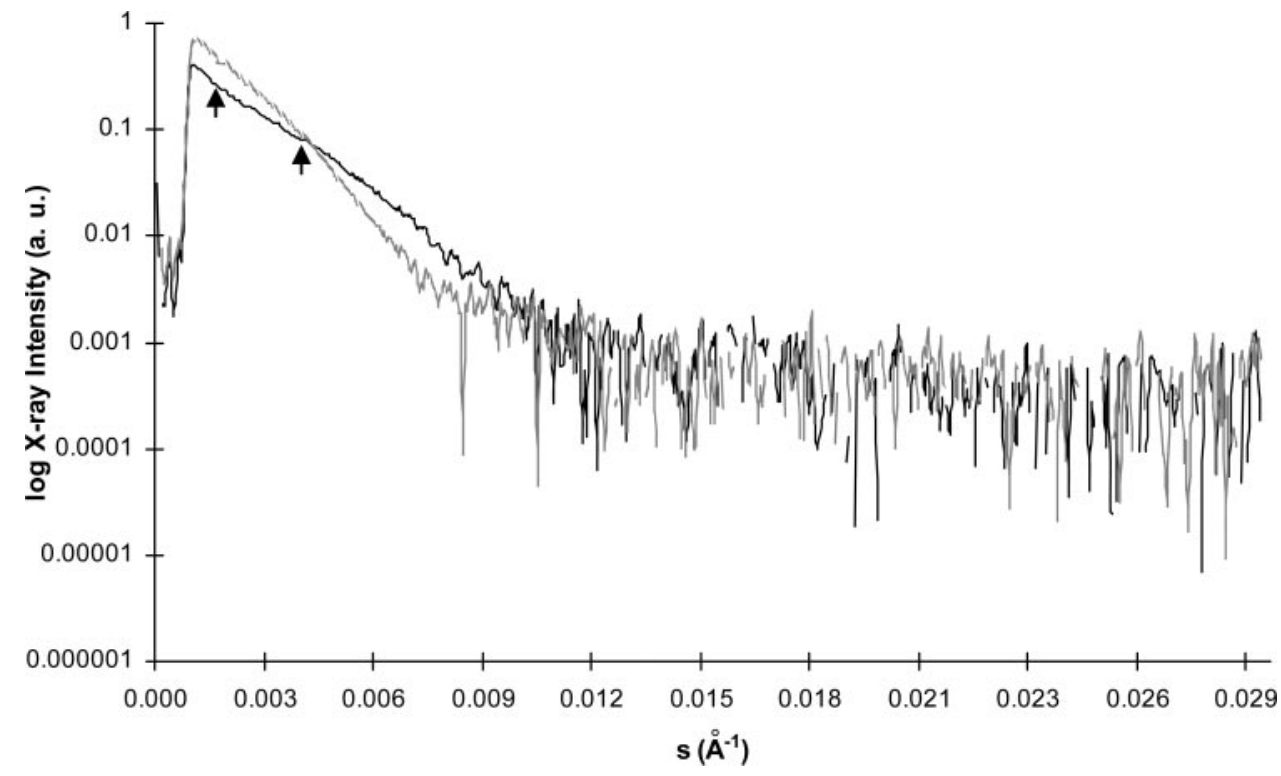

FigURE 1. X-ray-scattering intensity profiles of $\alpha$-crystallin at $35^{\circ} \mathrm{C}$ (black line) and $65^{\circ} \mathrm{C}$ (grey line). Arrows: limits of the Guinier region for the $35^{\circ} \mathrm{C}$ intensity profile. also made with heavy water (deuterium oxide; $\mathrm{D}_{2} \mathrm{O}$ ) rather than with normal water. For deuterium solutions, $\mathrm{pD}=\mathrm{pH}+0.4$, in all experiments, Guinier analysis was used to determine the average $\mathrm{Rg}$ of the protein aggregates as a function of temperature, in accordance with our earlier work. ${ }^{11} \mathrm{Rg}$ is derived from the Guinier region of the solution-scattering $x$-ray and neutron intensity profiles. Typical smallangle $\mathrm{x}$-ray-solution-scattering profiles of $\alpha$-crystallin at two different temperatures, $35^{\circ} \mathrm{C}$ and $65^{\circ} \mathrm{C}$, are shown in Figure 1 . The increase in intensity with increased temperature is due to the superaggregation process, discussed later. The two arrows indicate the limits of the Guinier region at $35^{\circ} \mathrm{C}$ in inverted space (S): $2 \times 10^{-3}$ to $4 \times 10^{-3} \AA^{-1}$ in this case. Such regions were then used to fit the Guinier approximation equation $^{14}$

$$
I=I_{0} \exp \left(-4 \pi^{2} \mathrm{~S}^{2} \mathrm{Rg}^{2} / 3\right)
$$

where $I$ is the scattered intensity and $I_{0}$ the forward scattering intensity. $\mathrm{Rg}$ is the root mean square distance of the electrons of the molecules in solution from the centers of their electronic masses and, therefore, is a measure of the overall size of the molecules. Exposure times were 1 and 5 minutes for the $\mathrm{x}$-ray and neutron experiments, respectively.

For the optical density experiments, similar solutions of $0.1 \mathrm{mg}$ $\mathrm{mL}^{-1} \alpha$-crystallin, $0.25 \mathrm{mg} \mathrm{mL}^{-1} \beta$-crystallin, or both combined, dissolved in buffered normal or heavy water were placed in 1-mL cuvettes preheated to $55^{\circ} \mathrm{C}$ in a spectrophotometer (model 930; Kontron America, Poway, CA) recording at $360 \mathrm{~nm} .{ }^{15}$ The solutions were left for 3 minutes to equilibrate at $55^{\circ} \mathrm{C}$, determined with a thermocouple thermometer (Comark, Beaverton, OR).

\section{Results}

Neutron- and $\mathrm{x}$-ray-scattering experiments on $\alpha$-crystallin in solution at $2 \mathrm{mg} \mathrm{mL}^{-1}$ indicate that $\mathrm{Rg}$ is $69 \pm 1 \AA$ at $35^{\circ} \mathrm{C}$ (Figs. 2A, 2B). In normal water, this $\mathrm{Rg}$ is essentially unchanged from $20^{\circ} \mathrm{C}$ to $50^{\circ} \mathrm{C}$, until superaggregation occurs above $50^{\circ} \mathrm{C}^{11}$ In deuterium-based solutions, however, $\mathrm{Rg}$ shows no sign of increase between $40^{\circ} \mathrm{C}$ and $55^{\circ} \mathrm{C}$ (Table 1 ). At $70^{\circ} \mathrm{C}, \mathrm{Rg}$ in heavy water is, on average, some 15 to $20 \AA$ smaller than $\mathrm{Rg}$ in hydrogen-based solutions, indicating an absence of superaggregation.

To investigate the chaperone activity of $\alpha$-crystallin in solution, we used $\beta$-crystallin, a protein that it protects in the lens, as the target protein. As demonstrated by Horwitz, ${ }^{7}$ optical density measurements of $\beta$-crystallin in an aqueous solution at
$2 \mathrm{mg} \mathrm{mL}^{-1}$ indicate that it denatures and precipitates at $55^{\circ} \mathrm{C}$. Above this temperature, too, $\mathrm{x}$-ray-scattering intensity was reduced, because most of the $\beta$-crystallin came out of solution (data not shown). This occurred even though one of its isoforms, $\beta \mathrm{B} 2$-crystallin, is known to unfold at high temperatures, but remains in solution, giving very high $\mathrm{Rg}$ (above $55^{\circ} \mathrm{C}$; Fig. 3). Optical density measurements of $\alpha+\beta$ solutions revealed that partial unfolding and precipitation of $\beta$-crystallin is prevented by the chaperone activity of $\alpha$-crystallin in both normal and heavy water solutions (Figs. 4A, 4B).

Measurements of $\mathrm{Rg}$ in the temperature range $20^{\circ} \mathrm{C}$ to $70^{\circ} \mathrm{C}$, for $\beta$-crystallin alone $\left(2 \mathrm{mg} \mathrm{mL}^{-1}\right)$, for $\alpha$-crystallin alone $(2 \mathrm{mg}$ $\mathrm{mL}^{-1}$ ), and for a mixture of $2 \mathrm{mg} \mathrm{mL}^{-1} \alpha$-crystallin plus $2 \mathrm{mg}$ $\mathrm{mL}^{-1} \beta$-crystallin (Table 2 ), revealed that $\mathrm{Rg}$ for $\beta$-crystallin is smaller than $\operatorname{Rg}$ for $\alpha$-crystallin by approximately $20 \AA$ (Fig. 4). $\mathrm{Rg}$ for proteins in solution is an average value for all molecules in the solution; thus, if $\alpha$-and $\beta$-crystallins acted independently, a reduced $\mathrm{Rg}$ would be expected from $\alpha+\beta$-crystallin in solution compared with $\alpha$-crystallin alone, as the $\beta$-crystallin aggregate is smaller $(40-200 \mathrm{kDa})$ than the $\alpha$-crystallin aggregate $(700 \mathrm{kDa})$. That this was manifestly not the case between $20^{\circ} \mathrm{C}$ and $35^{\circ} \mathrm{C}$, indicates that $\alpha$ - and $\beta$-crystallin interact in this temperature range. Above $35^{\circ} \mathrm{C}$, the $\mathrm{Rg}$ of $\alpha$-crystallin alone and of $\alpha+\beta$-crystallin diverged dynamically, but was almost identical (correlation coefficient, $R=0.995$ ) if the absolute temperature responses of the $\alpha+\beta$ aggregates were increased by $1.9 \%$.

\section{Discussion}

$\alpha$-Crystallin is a member of the small heat-shock protein (HSP) family. ${ }^{13}$ It has not been crystallized, but crystallographic structures of two HSPs have been identified, and there are similarities. ${ }^{16,17}$ The basic unit in both HSP-16.5 and -16.9 is a dimer of the C-terminal (hydrophilic) domains, common to all members of the small HSP family. Each dimer then interacts with two further dimers to form a tertiary structure building blockplanar and with three-fold symmetry. Quaternary structures of higher symmetry arise from these building blocks, governed by the packing of the dissimilar $\mathrm{N}$-terminal regions and C-terminal extensions. In HSP-16.5 this structure is roughly spherical, but has eight triangular and six square windows that give access to a central cavity. ${ }^{15}$ In wheat HSP-16.9 two similar planar sixmolecule building blocks are related by a rotated mirror plane, giving a quaternary structure that is a pair of apposed discs, 
A)

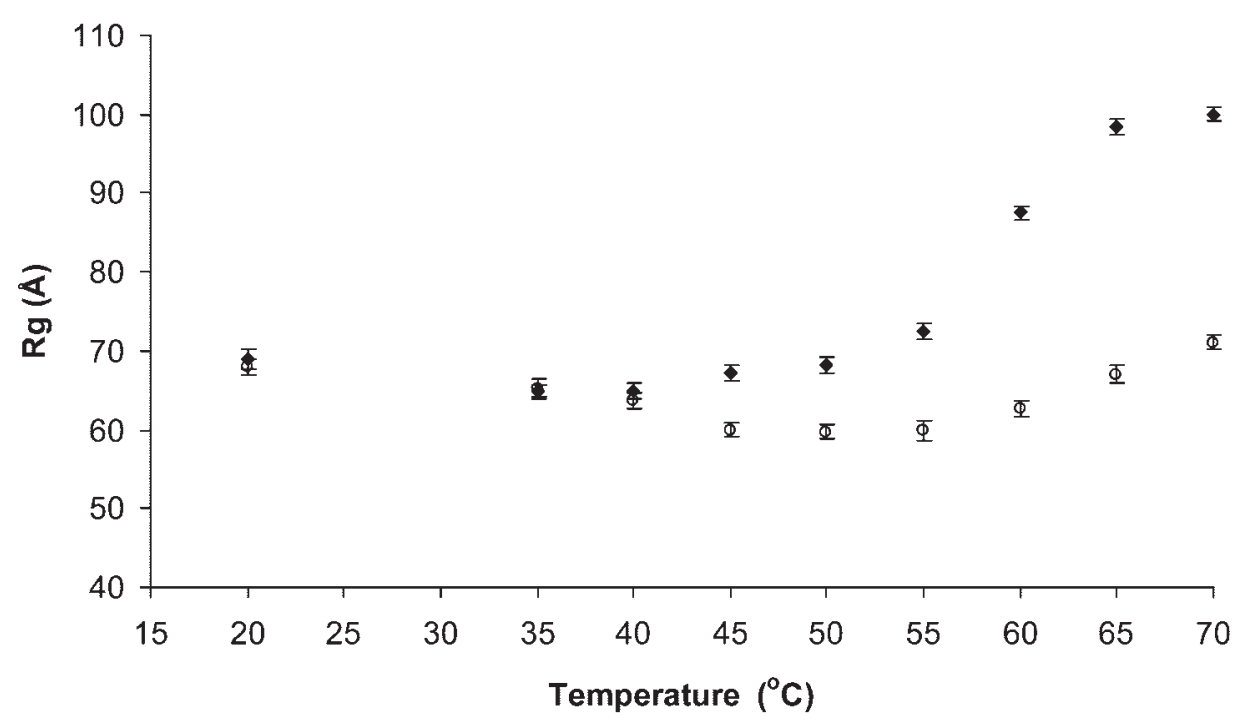

B)

FIGURE 2. (A) $\alpha$-Crystallin aggregate $\mathrm{Rg}$ in buffered $\mathrm{H}_{2} \mathrm{O}(\diamond)$ and $\mathrm{D}_{2} \mathrm{O}(\mathrm{O})$ solutions as a function of temperature, observed by neutron scattering. (B) $\alpha$-Crystallin aggregate $\mathrm{Rg}$ in buffered $\mathrm{H}_{2} \mathrm{O}(\diamond)$ and $\mathrm{D}_{2} \mathrm{O}(\mathrm{O})$ solutions as a function of temperature observed by $\mathrm{x}$-ray scattering. Error bars: the SD from the line of best fit in the Guinier region.

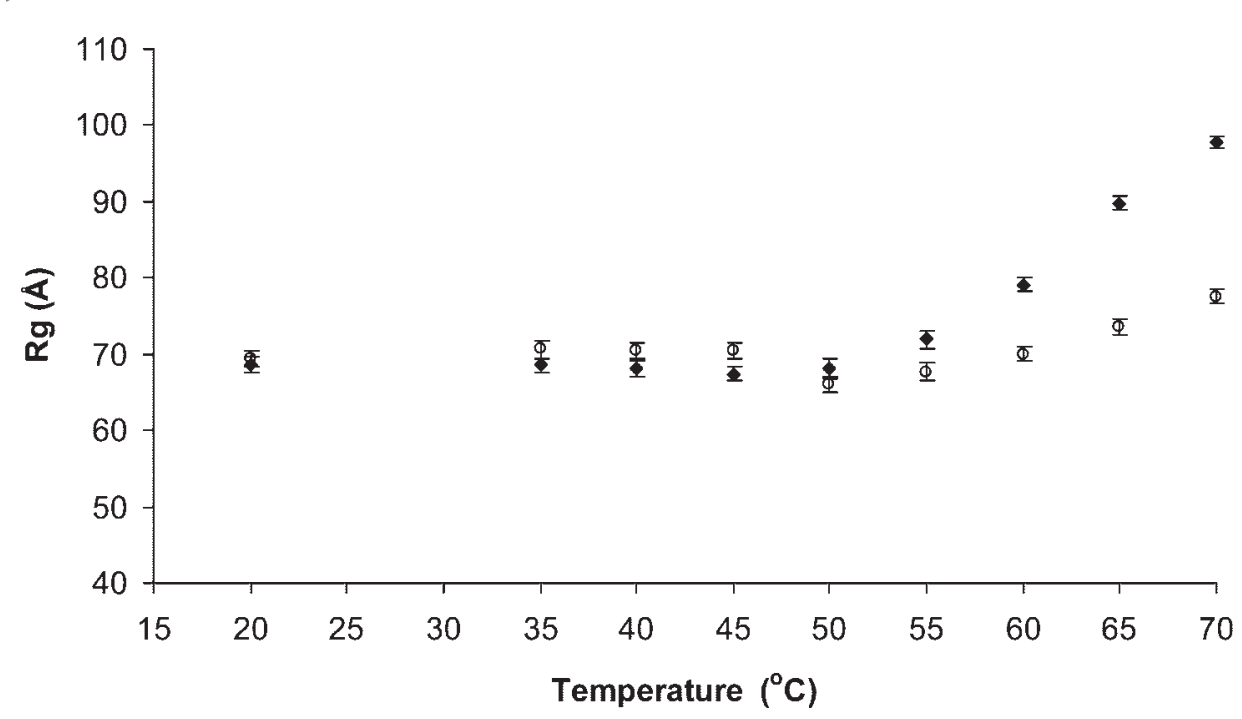

with one three-fold and three two-fold axes. ${ }^{17}$ Again, there is a central cavity, accessible from windows on either side of the structure along the three-fold axis.

A similar structure for $\alpha$-crystallin at physiological temperatures may be inferred from our data by the following reasoning. The specific volume occupancies of globular proteins are remarkably similar and lie in the range of 0.69 to $0.74 \mathrm{~mL}$ $\mathrm{g}^{-1} \cdot{ }^{18}$ Taking an average value of $0.72 \mathrm{~mL} \mathrm{~g}^{-1}$ for the $\alpha$-crystallin aggregate, together with its molecular mass of approximately $700 \mathrm{kDa}$ gives an estimated volume of $0.83 \times 106 \AA,^{3}$ with an uncertainty of approximately $20 \%$. A solid sphere with this volume would have a radius of approximately $58 \AA$.

The relationship between $\mathrm{Rg}$ and $\mathrm{r}$, the geometric radius, of any body is given by $r=k^{\prime} \times \mathrm{Rg}$, where $k^{\prime}$ is a constant with a numerical value that depends on the distribution of mass within the body. If $\alpha$-crystallin were a solid sphere of radius 58 $\AA, k^{\prime}$ would equal 1.581 . Therefore, the $\mathrm{Rg}$ of the sphere would be approximately $37 \AA$. This is clearly incompatible with our experimental value of $69 \pm 1$; thus, the packed spherical volume hypothesis is excluded by the data.

If we consider a thin solid spherical shell hypothesis for $\alpha$-crystallin in solution, though, $\boldsymbol{k}^{\prime}$ has a value of 1.225 . From our observed $\mathrm{Rg}$, the $\mathrm{Rg}$ of such a shell would then be $\sim 84.5$
$\AA$ (diameter, $169 \AA$ ). The surface area of such a spherical shell would be approximately $9 \times 10^{4} \AA^{2}$ giving room to accommodate a protein volume of $0.83 \times 10^{6} \AA^{3}$ in a layer approximately 10-A thick.

Support for the shell model for $\alpha$-crystallin comes from cryo-electron microscopy and three-dimensional image reconstruction studies of recombinant human $\alpha \mathrm{B}$-crystallin that suggest some sort of hollow sphere of diameter (for a 39-subunit aggregate) of $175 \pm 20 \AA .{ }^{19}$ This compares well with a fenestrated $\alpha$-crystallin sphere of 36 subunits (based on solved HSP structures), with a shell thickness of $9.8 \AA$ and a diameter of $169 \pm 2.6 \AA$. Carver et al. ${ }^{20}$ have used similar arguments to show that $\alpha$-crystallin aggregates must contain "space," though the model that they propose is barrel-shaped rather than spherical.

Figure 1 shows that in the experimental region beyond $\mathrm{S}=$ $9 \times 10^{-3} \AA^{-1}$, the $\mathrm{x}$-ray data become noisy and indistinct. This is the region where information may be sought from the particle Fourier transform, in monodisperse systems, and a shape reconstruction performed. One obvious cause of the lack of information in the data is that Fourier transforms from different-sized particles are overlaid and smear out the data. However, a recent $\mathrm{x}$-ray-solution-scattering study by Spinozzi 
TABLE 1. Rg of $\alpha$-Crystallin in Buffered $\mathrm{H}_{2} \mathrm{O}$ and $\mathrm{D}_{2} \mathrm{O}$ Solutions

\begin{tabular}{lcc}
\hline Method/Temp $\left({ }^{\circ} \mathbf{C}\right)$ & $\mathbf{H}_{\mathbf{2}} \mathbf{O} \pm \mathbf{S D}(\mathbf{A})$ & $\mathbf{D}_{\mathbf{2}} \mathbf{O} \pm \mathbf{S D}(\AA)$ \\
\hline $\begin{array}{l}\text { Neutron scattering } \\
20\end{array}$ & $69.0 \pm 1.12$ & $68.0 \pm 1.2$ \\
35 & $64.9 \pm 1.09$ & $65.3 \pm 0.87$ \\
40 & $64.9 \pm 1.14$ & $63.7 \pm 1.02$ \\
45 & $67.3 \pm 0.98$ & $60.0 \pm 0.99$ \\
50 & $68.2 \pm 1.02$ & $59.7 \pm 1.12$ \\
55 & $72.5 \pm 1.13$ & $59.9 \pm 0.95$ \\
60 & $87.5 \pm 0.95$ & $62.7 \pm 0.93$ \\
65 & $98.5 \pm 0.92$ & $67.0 \pm 1.0$ \\
70 & $100.0 \pm 0.84$ & $71.0 \pm 0.87$ \\
X-ray scattering & & \\
20 & $68.7 \pm 1.01$ & $69.4 \pm 0.99$ \\
35 & $68.5 \pm 1.02$ & $70.6 \pm 1.13$ \\
40 & $68.1 \pm 1.10$ & $70.5 \pm 1.09$ \\
45 & $67.4 \pm 0.93$ & $70.4 \pm 0.96$ \\
50 & $68.2 \pm 1.09$ & $65.9 \pm 0.91$ \\
55 & $71.9 \pm 1.17$ & $67.7 \pm 1.20$ \\
60 & $79.1 \pm 0.96$ & $70.0 \pm 0.94$ \\
65 & $89.8 \pm 0.90$ & $73.5 \pm 1.10$ \\
70 & $97.8 \pm 0.86$ & $77.6 \pm 0.89$ \\
\hline
\end{tabular}

et al. ${ }^{21}$ has used data from $\alpha \mathrm{B}$-crystallin, which is also polydisperse, to generate theoretical scattering curves in the noisy and indistinct region at different temperatures, based on the known structure of HSP16.9. The authors then created a general aggregation shape reconstruction model for all their experimental conditions. The resultant particle shape reconstruction resembles a distorted hollow sphere with a central cavity. Although the shape reconstruction is described by the authors as a snapshot of a polydisperse sphere, it complements the cryoelectron microscopy studies just mentioned ${ }^{19}$ and furthers our understanding of the possible underlying structure of $\alpha$-crystallin.

We have shown that the $\operatorname{Rg}$ of $(\alpha+\beta)$-crystallin below $35^{\circ} \mathrm{C}$ is $69 \pm 1 \AA$, the same as that of $\alpha$-crystallin alone (Fig. 3). This result implies that, under nonstress conditions, $\beta$-crystallin is not independent of $\alpha$-crystallin in solution, but weakly interacts with $\alpha$-crystallin, a contention that is backed up by nuclear magnetic resonance (NMR) studies. ${ }^{22}$ From simple mechanics, if $\beta$-crystallin were located on the outside of the $\alpha$-crystallin shell and if it were, in total, approximately the same molecular weight and density as the $\alpha$-crystallin, we would expect to see an approximate increase in $\mathrm{Rg}$ of $\sim 4 \AA$. Alternatively, if it were on the inside of the shell, we would expect to see an approximate $4 \AA$ decrease in the $\operatorname{Rg}$ of the $\alpha+\beta$ aggregate. Thus, our data point to a model with the targeted $\beta$-crystallin coplanar in

A)

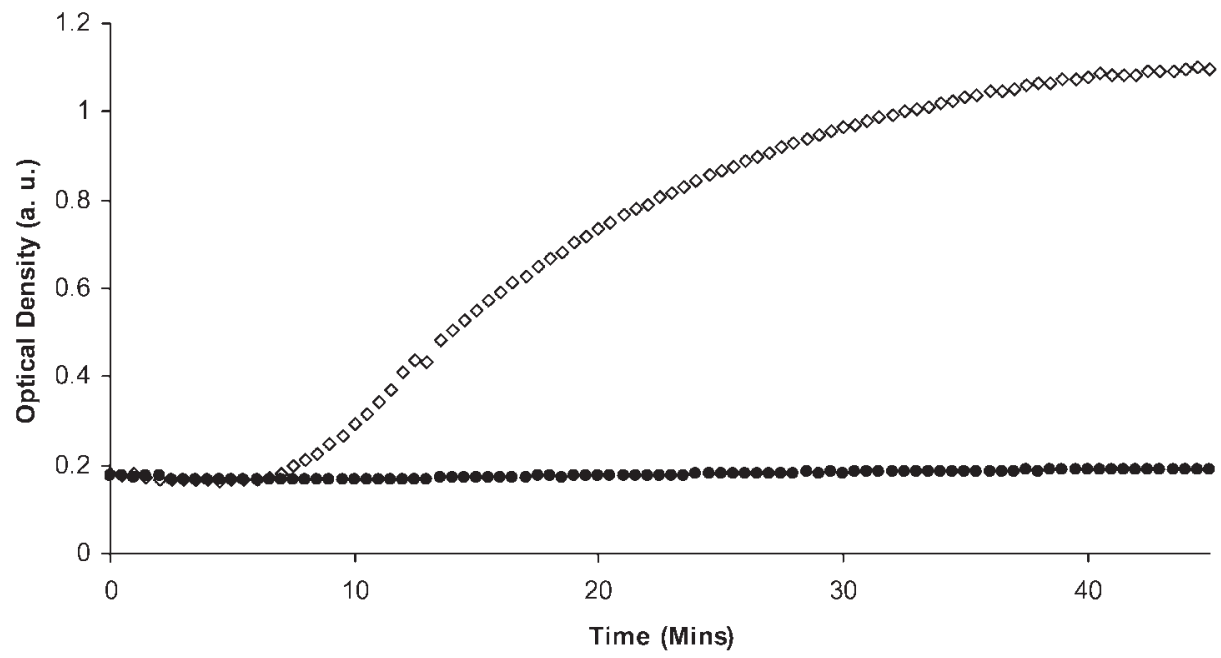

B)

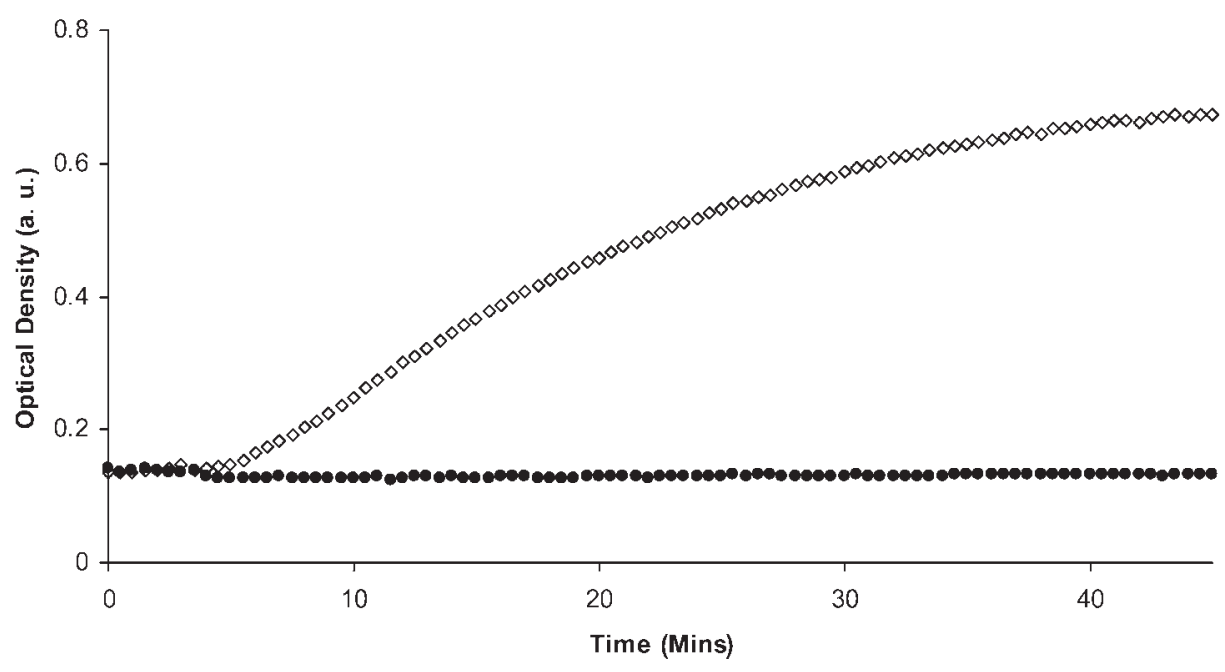

Figure 3. The light-scattering (optical density) of $\beta$-crystallin $(\diamond)$, and $\alpha+\beta$-crystallin ( $\diamond$ ) (subunit molar ratio of $\alpha$ to $\beta, 0.5: 1)$ at $56^{\circ} \mathrm{C}$ in (A) buffered $\mathrm{H}_{2} \mathrm{O}$ solution and (B) buffered $\mathrm{D}_{2} \mathrm{O}$ solution. 
FIGURE 4. The $\mathrm{Rg}$ of $\alpha$-crystallin $(\bigcirc), \beta$-crystallin $(\triangle)$, and $\alpha+\beta$-crystallin (๑) (subunit molar ratio of $\alpha$ to $\beta, 1.25: 1$ ), as a function of temperature observed by $\mathrm{x}$-ray scattering. Error bars: SD from the line of best fit in the Guinier region.

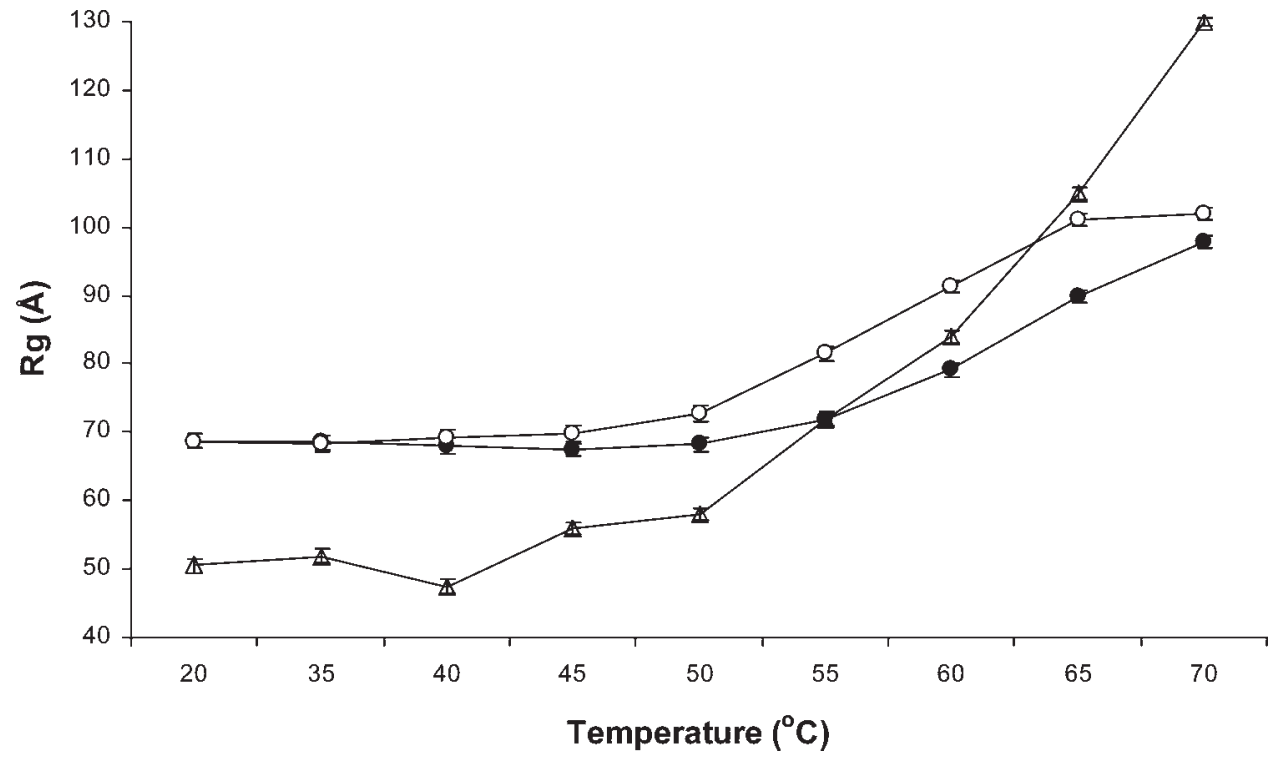

the windows in the surfaces of the $\alpha$-crystallin shell precisely because experimentally we see no change in Rg. At higher temperatures, the situation is more complicated; the subunit exchange of both isoforms of $\alpha$-crystallin, are known to increase with higher association and disassociation rates with increasing temperatures. ${ }^{23,24}$ The possibility exists that a higher number of $\beta$-monomers chaperoned by the $\alpha$-crystallin, or the higher mobility of each monomer, causes an increase in the size $(\mathrm{Rg})$ of the $\alpha$-crystallin superaggregates. This increase may be caused by swelling induced by the chaperone function, or by aggregation on the outside of the $\alpha$-aggregates, or by both of these mechanisms.

The deuterium bond is more stable than the hydrogen bond by 0.1 to $0.2 \mathrm{kcal}^{\mathrm{mole}} \mathrm{e}^{-1}$ and thus needs greater activation energy for cleavage. ${ }^{25}$ The different aggregation process of $\alpha$-crystallin in hydrogen- and deuterium-based solutions indicates the importance of hydrogen bonding. It is likely that as the aggregates increase in size with temperature in normal water, intersheet hydrogen bonds are cleaved more easily and may allow for subunit exchange and recruitment that leads to a swelling and/or mass increase of spherical shells. Particle size measurements using photocorrelation techniques show that in the temperature range from $4^{\circ} \mathrm{C}$ to $50^{\circ} \mathrm{C}, \alpha$-crystallin actually decreases in molecular mass and size. ${ }^{26,27}$ From $4^{\circ} \mathrm{C}$ to $20^{\circ} \mathrm{C}$ the hydrodynamic diameter $\left(D_{\mathrm{H}}\right)$ of $\alpha$-crystallin is stable but steadily decreases from $20^{\circ} \mathrm{C}$ and reaches a minimum at $40^{\circ} \mathrm{C}$, before increasing dramatically at $50^{\circ} \mathrm{C}$. As mentioned, the deuterium bond is stronger than the hydrogen bond, and it is probable that higher temperatures than $70^{\circ} \mathrm{C}$ are necessary

TABLE 2. Rg $\alpha$-Crystallin, $\alpha+\beta$-Crystallin, and $\beta$-Crystallin Observed by X-ray Scattering

\begin{tabular}{cccc}
\hline Temperature $\left({ }^{\circ} \mathbf{C}\right)$ & $\boldsymbol{\alpha} \pm \mathbf{S D}(\AA)$ & $\boldsymbol{\alpha}+\boldsymbol{\beta} \pm \mathbf{S D}(\mathbf{\AA})$ & $\boldsymbol{\beta} \pm \mathbf{S D}(\AA)$ \\
\hline 20 & $68.7 \pm 1.01$ & $68.7 \pm 1.08$ & $50.5 \pm 1.15$ \\
35 & $68.5 \pm 1.06$ & $68.4 \pm 1.16$ & $51.9 \pm 0.98$ \\
40 & $68.1 \pm 1.20$ & $69.2 \pm 1.23$ & $47.5 \pm 1.14$ \\
45 & $67.4 \pm 0.95$ & $69.7 \pm 1.14$ & $55.9 \pm 0.97$ \\
50 & $78.2 \pm 1.09$ & $72.7 \pm 1.25$ & $58.0 \pm 0.96$ \\
55 & $71.9 \pm 1.15$ & $81.5 \pm 1.04$ & $71.9 \pm 0.81$ \\
60 & $79.1 \pm 0.95$ & $91.4 \pm 0.92$ & $83.9 \pm 0.91$ \\
65 & $89.8 \pm 0.91$ & $101 \pm 0.84$ & $105 \pm 0.86$ \\
70 & $97.8 \pm 0.86$ & $102 \pm 0.84$ & $130 \pm 0.61$
\end{tabular}

The subunit molar ratio of $\alpha$ to $\beta$ was $1.25: 1$. The standard deviation is taken from the line of best fit in the Guinier region. before $\alpha$-crystallin undergoes superaggregation in $\mathrm{D}_{2} \mathrm{O}$. Similarly, the decrease in the $\mathrm{Rg}$ of $\alpha$-crystallin in $\mathrm{D}_{2} \mathrm{O}$ that we observe from our neutron and $\mathrm{x}$-ray studies for $40^{\circ} \mathrm{C}$ to $60^{\circ} \mathrm{C}$ is likely to be due to the same dynamic behavior of the particles observed by photocorrelation techniques at lower temperatures in $\mathrm{H}_{2} \mathrm{O}$-based solutions, but shifted to a higher temperature range. It should be noted that the decrease in particle size at $\sim 40^{\circ} \mathrm{C}$ is dependent on the protein concentration. In our neutron- and x-ray-scattering studies and in the photocorrelation techniques, protein concentrations were below $10 \mathrm{mg}$ $\mathrm{mL}^{-1}$. In our previous study, ${ }^{11}$ we used $\alpha$-crystallin gels (300 $\mathrm{mg} \mathrm{mL}^{-1}$ ) and did not observe this effect.

The lack of superaggregation in deuterium-based solutions and the fact that $\alpha$-crystallin is still a functional chaperone in such solutions implies that the two processes are not linked.

\section{Acknowledgments}

The authors thank Alun Thomas for assisting in the neutron experiments.

\section{References}

1. de Jong WW. Molecular and Cellular Biology of the Eye Lens. New York; 1981.

2. Bhat SP, Nagineni CN. alpha B subunit of lens-specific protein alpha-crystallin is present in other ocular and non-ocular tissues. Biochem Biophys Res Commun. 1989;158:319-325.

3. Kato K, Shinohara H, Kurobe N, Inaguma Y, Shimizu Y, Oshima K. Tissue distribution and developmental profiles of immunoreactive alpha B crystallin in the rat determined with a sensitive immunoassay system. Biochim Biophys Acta. 1991;1074:201-208.

4. Harding J. Cataract: Biochemistry, Epidemiology and Pharmacology. London: Chapman and Hall; 1991.

5. Delaye M, Tardieu A. Short-range order of crystallin proteins accounts for eye lens transparency. Nature. 1983;302:415-417.

6. Farahbakhsh ZT, Huang QL, Ding LL, et al. Interaction of alphacrystallin with spin-labeled peptides. Biochemistry. 1995;34:509516.

7. Horwitz J. Alpha-crystallin can function as a molecular chaperone. Proc Natl Acad Sci USA. 1992;89:1449-1453.

8. Heath MM, Rixon KC, Harding JJ. Glycation-induced inactivation of malate dehydrogenase protection by aspirin and a lens molecular chaperone, alpha-crystallin. Biochim Biophys Acta. 1996;1315: $176-184$.

9. Chiesi M, Longoni S, Limbrruno U. Cardiac alpha-crystallin. III. Involvement during heart ischemia. Mol Cell Biochem. 1990;97: 129-136. 
10. van Noort JM, van Sechel AC, Bajramovic JJ, et al. The small heat-shock protein alpha B-crystallin as candidate autoantigen in multiple sclerosis. Nature. 1995;375:798-801.

11. Regini JW, Grossman JG, Burgio MR, et al. Structural changes in alpha-crystallin and whole eye lens during heating, observed by low-angle X-ray diffraction. J Mol Biol. 2004;336:1185-1194.

12. Burgio MR, Kim CJ, Dow CC, Koretz JF. Correlation between the chaperone-like activity and aggregate size of alpha-crystallin with increasing temperature. Biochem Biophys Res Commum. 2000; 268:426- 432 .

13. Derham BK, Harding JJ. Effects of modifications of alpha-crystallin on its chaperone and other properties. Biochem J. 2002;364:711717 .

14. Guinier A, Fournet F. Small Angle Scattering of X-Rays. New York: Wiley Interscience; 1955.

15. Ganea E, Harding JJ. Molecular chaperones protect against glycation-induced inactivation of glucose-6-phosphate dehydrogenase. Eur J Biochem. 1995;231:181-185.

16. Kim KK, Kim R, Kim SH. Crystal structure of a small heat-shock protein. Nature. 1998;394:595-599.

17. van Montfort RL, Basha E, Friedrich KL, Slingsby C, Vierling E. Crystal structure and assembly of a eukaryotic small heat shock protein. Nat Struct Biol. 2001;8:1025-1030.

18. Chalikian TV, Totrov M, Abagyan R, Breslauer KJ. The hydration of globular proteins as derived from volume and compressibility measurements: cross correlating thermodynamic and structural data. J Mol Biol. 1996;260:588-603.

19. Haley DA, Horwitz J, Stewart PL. Image restrained modeling of alphaB-crystallin. Exp Eye Res. 1999;68:133-136.

20. Carver JA, Aquilina JA, Truscott RJ. A possible chaperone-like quaternary structure for alpha-crystallin. Exp Eye Res. 1994;59: 231-234.

21. Spinozzi F, Mariani P, Rustichelli F, et al. Temperature dependence of chaperone-like activity and oligomeric state of alphaB-crystallin. Biochim Biophys Acta. 2006;1764:667-687.

22. Lindner RA, Treweek TM, Carver JA. The molecular chaperone alpha-crystallin is in kinetic competition with aggregation to stabilize a monomeric molten-globule form of alpha-lactalbumin. Biochem J. 2001;354:79-87.

23. Bova MP, Ding L-L, Horwitz J, Fung, BK-K. Subunit exchange of alphaA-crystallin. J Biol Chem. 1997;272:29511-29517.

24. Liu L, Ghosh JG, Clark JI, Jiang S. Studies of alphaB-crystallin subunit dynamics by surface plasmon resonance. Anal Biochem. 2006;350:186-195.

25. Cioni P, Strambini GB. Effect of heavy water on protein flexibility. Biophys J. 2002;82:3246-3253.

26. Vanhoudt J, Aerts T, Abgar S, Clauwert J. Quaternary structure of bovine alpha-crystallin: influence of temperature. Int $\mathrm{J} \mathrm{Biol}$ Macromol. 1998;22:229-273.

27. Vanhoudt J, Abgar S, Aerts T, Clauwert J. Native quaternary structure of bovine $\alpha$-crystallin. Biocbemistry. 2000;39:4483-4492. 